\title{
INFLUENCE OF IRRIGATION LEVELS AND PLANT DENSITY ON "SECOND-SEASON" MAIZE ${ }^{1}$
}

\author{
LUIS HUMBERTO BAHÚ BEN ${ }^{2 *}$, MARCIA XAVIER PEITER ${ }^{2}$, ADROALDO DIAS ROBAINA $^{2}$, ANA RITA \\ COSTENARO PARIZI ${ }^{3}$, GIDEON UJACOV DA SILVA ${ }^{4}$
}

\begin{abstract}
This study assessed the effect of different irrigation levels and plant densities on maize crops cultivated during the second season in the Western Border region of the State of Rio Grande do Sul. This work was conducted at the Federal Institute of Farroupilha - Alegrete Campus/RS - between January and June 2014. Treatments were arranged in a completely randomized $5 \times 4$ factorial design, with 3 replicates each. Irrigation of fixed amounts of water that were based on the evapotranspiration of the culture $\left(\mathrm{Et}_{\mathrm{c}}\right): 0,50,75,100$, and

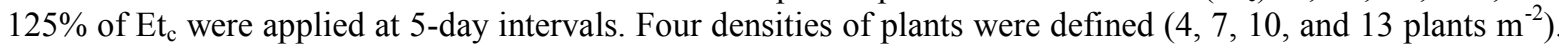
We assessed number of maize ears per plant, number of grains per ear, aboveground dry matter, mass of 100 grains, harvest index, and grain productivity. The number of grains per ear, mass of 100 grains, and grain yield were influenced by irrigation levels. Plant density and water depth influenced the number of grains per ear, the mass of 100 grains, and grain productivity. The highest yield of winter maize grain was achieved with a combination of 13 plants per $\mathrm{m}^{-2}$ and an irrigation level of $100 \% \mathrm{of} \mathrm{Et}_{\mathrm{c}}$. Specific densities of plants maximized the yield of maize at each irrigation level, demonstrating that choice of plant density is a critical variable in the second crop of maize, and significantly influences the components of production.
\end{abstract}

Keywords: Zea mays L.. Irrigation management. Yield components.

\section{INFLUÊNCIA DE LÂMINAS DE IRRIGAÇÃO E DENSIDADE DE PLANTAS NO MILHO "SAFRINHA"}

\begin{abstract}
RESUMO - O objetivo do presente estudo foi avaliar o efeito de diferentes lâminas de irrigação e densidades de plantas sobre o milho safrinha na região Fronteira Oeste do Estado do RS. O trabalho foi conduzido no Instituto Federal Farroupilha - Campus de Alegrete/RS, no período de janeiro a junho de 2014. Os tratamentos foram dispostos em um delineamento Inteiramente casualizado, fatorial 5 x 4 com 3 repetições. As irrigações foram realizadas em turno de rega fixo de cinco dias e a lâmina aplicada, com base na evapotranspiração da cultura $\left(\mathrm{Et}_{\mathrm{c}}\right)$. Os tratamentos foram 0, 50, 75, 100 e 125\% da Et $\mathrm{c}_{\mathrm{c}}$. Foi definido quatro densidades de plantas (4; 7; 10 e 13 plantas $\mathrm{m}^{-2}$ ). Avaliou-se: número de espigas por planta, número de grãos por espiga, matéria seca da parte aérea, massa de cem grãos, índice de colheita e produtividade de grãos. O número de grãos por espiga, a massa de cem grãos e a produtividade de grãos são influenciados pelas lâminas de irrigação. A densidade de plantas e a lâmina de irrigação influenciaram no número de grãos por espiga, massa seca da parte aérea e produtividade de grãos. A maior produtividade de grãos do milho safrinha foi encontrada na combinação de 13 plantas $\mathrm{m}^{-2}$ com a lâmina de irrigação de $100 \%$ da Etc. Existe uma densidade de plantas que maximiza o rendimento de grãos de milho para cada lâmina de irrigação adotada. A escolha da densidade de plantas é uma variável decisiva no cultivo de milho safrinha, influenciando significativamente nos componentes de produção.
\end{abstract}

Palavras chaves: Zea mays L. Manejo de irrigação. Componentes de produção.

\footnotetext{
*Corresponding author

${ }^{1}$ Received for publication in $03 / 24 / 2015$; accepted in 04/22/2016.

Paper extracted from the masters dissertation of the first author.

${ }^{2}$ Rural Engineering Department, Universidade Federal de Santa Maria, Santa Maria, RS, Brazil; luishumbertoben@hotmail.com, mpeiter@gmail.com,diasrobaina@gmail.com.

${ }^{3}$ Instituto Federal Farroupilha, Campus Alegrete, Alegrete, RS, Brazil; ana.parizi@iffarroupilha.edu.br.

${ }^{4}$ Instituto Federal Farroupilha, Campus Alegrete, Universidade federal do Pampa campus Alegrete, Alegrete, RS, Brazil. gideonujacov@yahoo.com.br.
} 


\section{INTRODUCTION}

The yield of maize grain is a complex variable that depends on the interaction between genetic, environmental, and management factors (KAPPES et al., 2011). There are several causes of a low crop yield, in particular insufficient availability of water and nutrients in the soil, incorrect soil management, and inappropriate sowing density (SILVA et al., 2003). According to Serpa et al. (2012), to achieve high yield of maize grain (Zea mays L.), it is necessary to adapt management practices to the resources available in each cultivation environment to provide the best conditions for plant development.

In the State of Rio Grande do Sul (RS), water availability is one of the most common and important factors that affects grain yield of maize crops. Kopp et al. (2015) studied four sowing dates between 1992 to 2012 in three municipalities of RS, and concluded an average water supplement of 393 $\mathrm{mm}$ was needed for maize, based on an average reduction of $55.2 \%$ in grain yield during the study period. As such, supplementary water was emphasized as one of the techniques necessary to stabilize the production of maize (MINUZZI; RIBEIRO, 2012). Bergamaschi et al. (2006) observed, from a ten-year field experiment in the city of Eldorado do Sul, RS, that total irrigation provided an increase of nearly $70 \%$ in maize yield compared with non-irrigated crops. Moreover, Vieira et al. (2013) also found a significant increase in irrigated crops compared with non-irrigated plants.

Another important factor that increases and exploits the productive potential of maize is the arrangement of plants, especially when combined with irrigation treatments. Currently, tests of maize seed by production companies are completed either in a completely dry or $100 \%$ irrigated system, without specifically examining partially irrigated plant populations (PEAKE et al., 2006). According to Brachtvogel et al. (2009), population densities are between 70,000 and 100,000 plants $\mathrm{ha}^{-1}$, depending on the company, location, and hybrid used. However, authors, such as Piana et al. (2008) and Takasu et al. (2014), suggested densities between 107,000 and 100,000, for fully irrigated systems. Similarly, Silva et al. (2010) found that the productive potential of irrigated maize was obtained at 90,000 plants per ha ${ }^{-1}$. However, Brachtvogel et al. (2012) reported a higher yield in populations of 65,000 plants per $\mathrm{ha}^{-1}$ without the use of supplemental irrigation. Thus, it appears that there are several studies of plant density, yet none of these studies considers the management of arrangements of rainfed and fully irrigated crops with intermediate water depth. A further consideration is the importance of assessing plant densities for cultivating maize in different conditions of water availability and second-season cultivation.
Maize sowing during the winter-harvest, or "safrinha", takes place between the months of December and January in RS. This cultural period has increased in recent decades, due to the practice of cultivating in spring or for maize crops replacing spring beans or tobacco. (BERGAMASCHI; MATZENAUER, 2014). According to Basso et al. (2013), winter maize in RS is also used in the production of straw, contributing to the sustainability of the no-till system, and in most of the properties the sequence of oat, maize silage, and second-season crop is the most widely used.

This study assessed the effect of different irrigation levels and plant densities on maize crops grown during the second-season period in the Western Border region of RS.

\section{MATERIAL AND METHODS}

The experiment was conducted in the experimental area of the Irrigation and Drainage Sector of the Federal Institute of Farroupilha Campus Alegrete - in the municipality of Alegrete,

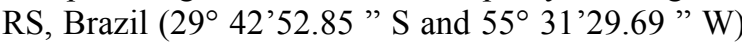
at an altitude of $121 \mathrm{~m}$. The soil in the experimental area is a sandy "Dystrophic Red Argisol") Brazilian Soil Classification) (STRECK et al., 2008), with a particle size of $62.6,12.1$, and $25.2 \mathrm{~g} \mathrm{Kg}^{-1}$ for sand, silt, and clay, respectively.

The experimental area was cleared 45 days prior to sowing, using glyphosate $\left(1,800 \mathrm{~g} \mathrm{ha}^{-1}\right.$ of the a.i.) and 2.4-D (670 $\mathrm{g} \mathrm{ha}^{-1}$ of the a.i.) as a herbicide. To control weeds during the experiment, glyphosate $\left(1,800 \mathrm{~g} \mathrm{ha}^{-1}\right.$ of the a.i.) was applied twice at 11 and 37 days after emergence, as the maize hybrid used is resistant to this herbicide.

The experiment consisted of a completely randomized $5 \times 4$ factorial design with three replicates. Five different supplemental irrigation depths were used $\left(0-\mathrm{T}_{0}, 50-\mathrm{T}_{1}, 75-\mathrm{T}_{2}, 100-\mathrm{T}_{3}\right.$, and $125-\mathrm{T}_{4} \%$ of evapotranspiration of the crop $-\mathrm{Et}_{\mathrm{c}}$ ) with four plant densities $\left(4,7,10\right.$, and 13 plants $\left.\mathrm{m}^{-2}\right)$. Dimensions of the plots were $6.00 \mathrm{~m} \times 2.25 \mathrm{~m}$, with six rows of sowing, $0.45 \mathrm{~m}$ apart.

The simple early cycle maize hybrid Dekalb 250 Pro 2 was sown on January 6, 2014, using a mechanical seeder, under turnip straw, with a distance of $0.45 \mathrm{~m}$ between rows, and approximately seven seeds per meter ( 15 plants per $\left.\mathrm{m}^{-2}\right)$. After sowing, different population densities were established by thinning at fifteen days after emergence (DAE). Seeds contained the transgenic gene YieldGard ${ }^{\circledR}$ to control caterpillars and glyphosate-based Roundup Ready ${ }^{\circledR}$, which is herbicide tolerant. Seeds were also previously treated with insecticide Thiamethoxam (Cruiser), and with fungicide fludioxonil metalaxyl (Maxim XL), to control pests and diseases in the early stage of the crop cycle. 
For basic fertilization, $450 \mathrm{~kg} \mathrm{ha}^{-1}$ of NPK was applied close to sowing, in a ratio of 5:20:20, and two applications of $90 \mathrm{~kg} \mathrm{ha}^{-1}$ of $\mathrm{N}$ in the form of urea was used for the top-dressing, at 15 and 34 DAE, stages V3 and V8, respectively (RITCHIE, et al., 1993). Fertilizer was applied as per the instructions of the soil fertility report, interpreted using the Fertilization and Liming Manual of Agricultural Crops for the States of RS and SC.

The maize harvest was performed manually for individual experimental units at $135 \mathrm{DAE}$, when grains contained approximately $20 \%$ moisture. Harvested material was oven-dried at $65{ }^{\circ} \mathrm{C}$ and the productivity and final moisture components were subsequently measured.

Irrigation was performed by a conventional sprinkler-type system with spacing of $12 \mathrm{~m} \times 12 \mathrm{~m}$, consisting of a main row measuring $48 \mathrm{~m}$ and five side rows measuring $24 \mathrm{~m}$. Sprinklers (Naan brand, model 5022) were full turn, with different nozzles used for each side row, as follows: $4.0 \mathrm{~mm} \times 2.5 \mathrm{~mm}$ in rows one and two; $3.2 \mathrm{~mm} \times 2.5 \mathrm{~mm}$ for row three, and $2.1 \mathrm{~mm} \times 2.5 \mathrm{~mm}$ for rows four and five. The inlet pressure of the main row was $2.7410^{2} \mathrm{kPa}$. Different irrigation levels were applied by overlapping water through the different diameters of the sprinkler nozzles. Irrigation was applied at fixed intervals of five days, and the levels applied were based on daily readings of the Class A Tank Evaporation (EV). The volume of water applied was calculated by multiplying the accumulation of five days of EV by the tank coefficient $(\mathrm{Kp})$ and the crop coefficient $(\mathrm{Kc})$, following the methods of Büchele and Silva (1992) and Doorenbos and Kassan (1979), respectively. Meteorological data to calculate $\mathrm{Kp}$ were collected from a National Institute of Meteorology weather station - located $500 \mathrm{~m}$ from the experimental area. To calculate effective rain, a lysimeter was used with maize plants at the same stage as the test plants, located $15 \mathrm{~m}$ from the experimental area. At each rainfall event, the runoff measured was subtracted from the rainfall measured at the weather station. Deep percolation was not considered in the calculation of effective rainfall. After the installation of irrigation equipment in the experimental area, the Christiansen's uniformity coefficient (CUC) test was used to verify and calibrate irrigation levels.

The amount of irrigation, levels applied, and rainfall measured during the experiment are shown in Table 1.

Table 1. Amount of irrigation $(\mathrm{mm})$, total irrigation $(\mathrm{mm})$, average level applied by irrigation $(\mathrm{mm})$, effective rainfall $(\mathrm{mm})$, and total water applied (mm) to maize cultures.

\begin{tabular}{lccccc}
\hline Treatment & $\begin{array}{c}\text { Amount of } \\
\text { Irrigation } \\
(\mathrm{mm})\end{array}$ & $\begin{array}{c}\text { Irrigation } \\
\text { Total }\end{array}$ & $\begin{array}{c}\text { Average level } \\
\text { applied by irrigation }\end{array}$ & $\begin{array}{c}\text { Effective } \\
\text { rainfall } \\
(\mathrm{mm})\end{array}$ & $\begin{array}{c}\text { Total } \\
\text { water applied }\end{array}$ \\
\hline $0-$ Control & 0 & 00.0 & 0.0 & 618 & 618 \\
$1-50 \% \mathrm{Et}_{\mathrm{c}}$ & 10 & 83.9 & 8.4 & 618 & 701.74 \\
$2-75 \% \mathrm{Et}_{\mathrm{c}}$ & 10 & 125.9 & 12.6 & 618 & 743.70 \\
$3-100 \% \mathrm{Et}_{\mathrm{c}}$ & 10 & 167.8 & 16.8 & 618 & 785.65 \\
$4-125 \% \mathrm{Et}_{\mathrm{c}}$ & 10 & 209.8 & 21.0 & 618 & 827.61 \\
\hline
\end{tabular}

Figure 1 shows the timing of irrigation, and the amount of effective cumulative rainfall every five days. During the maize cultivation season, there were 10 irrigations, two in the growing season (emergence up to $54 \mathrm{DAE}$ ) and eight in the reproductive period. It should be noted that the total volume of effective rainfall measured during the trial was $618 \mathrm{~mm}$, which would adequately meet the water requirements of maize. Fancelli (2001) defined the water requirements for such crops in Rio Grande do Sul as between 400 and $600 \mathrm{~mm}$ during their cycle (extra early-maturing, early-maturing or late-maturing). However, the distribution of rain during the experiment was irregular, with periods of scarcity, and thus, rainfall was supplemented with additional irrigation when necessary. It should be noted that there were intervals of up to fifteen days without precipitation. Such periods of rainfall shortage are sufficient to influence the main maize productivity components assessed in this study, as discussed below.

The following agronomic characteristics were assessed: number of ears per plant - NEP; number of grains per ear - NGE (obtained by manual counting of the grains after harvest); mass of 100 grains MCG (mass in grams, obtained after drying the grains and corrected to $13 \%$ humidity); total aboveground dry matter by area - MS (weight in $\mathrm{kg}$ obtained by drying ten plants per plot and extrapolating to tons per hectares - $\mathrm{t} \mathrm{ha}^{-1}$ ); harvest index - IC (fraction of grain productivity in relation to total aboveground dry matter); and grain productivity - Pgrains (in $\mathrm{t} \mathrm{ha}^{-1}$ estimated by equation 1).

Pgrains $\left(t h a^{-1}\right)=\frac{\text { plant density } m^{-2} \times N E P \times N G E \times M C G(g)}{10000}$ Eq.1 


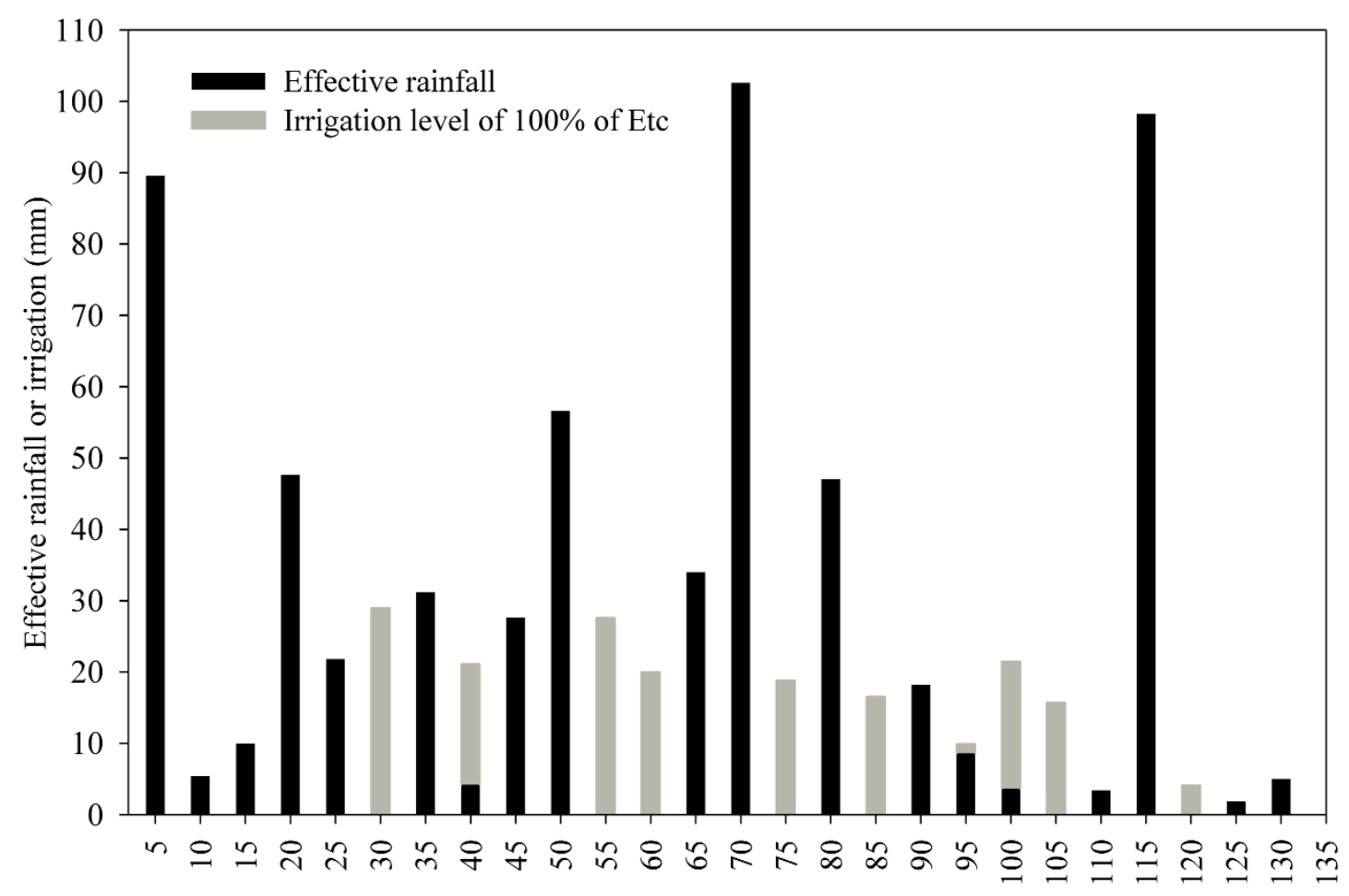

Days after emergence

Figure 1. Effective rainfall and irrigation (at $100 \%$ water replacement of evapotranspiration) applied to growing cultures every five days in second-season maize.

The data were statistically tested using analysis of variance (ANOVA). Means were subjected to regression analysis (linear, quadratic, cubic, and interactions between factors). We considered only significant effects, indicated by the F-test $(p<0.05)$. When there were multiple individual effects for a treatment, we chose the significant effect that showed a greater coefficient of determination, and therefore would better explain the biological responses of maize. For the interactions between factors (levels of irrigation and plant density) we created surface charts of the responses. For statistical analysis, we used Sisvar 5.3 software
(FERREIRA, 1998).

\section{RESULTS AND DISCUSSION}

The number of ears per plant (NEP) showed a linear decrease with increasing density of plants, declining from 1.28 ears per plant at a density of four plants per $\mathrm{m}^{-2}$, to 1.0 at a density of 10 and 13 plants per $\mathrm{m}^{-2}$ (Figure 2). There was no statistically significant effect of irrigation levels on the NEP (Table 2), as there was an average of 1.10 ears per plant in all irrigation level treatments.

Table 2. ANOVA error probability and coefficient of variation (CV) for the number of ears per plant (NEP), number of grains per ear (NGE), mass of 100 grains (MCG), aboveground dry matter productivity (MS), harvest index (HI), and grain productivity (Pgrains), for maize crops grown at different levels of irrigation and plant density.

\begin{tabular}{lcccccc}
\hline \multicolumn{1}{c}{ Treatment } & NEP & NGE & MCG & MS & HI & Pgrains \\
\hline Irrigation Levels & $0.582^{\mathrm{ns}}$ & $0.011^{*}$ & $0.001^{*}$ & $0.000^{* *}$ & $0.622^{\mathrm{ns}}$ & $0.000^{* *}$ \\
Linear regression & - & - & $0.000^{* *}$ & - & - & - \\
Quadratic regression & - & - & $0.027^{*}$ & - & - & - \\
Plant density & $0.000^{*}$ & $0.000^{* *}$ & $0.001^{* *}$ & $0.000^{* *}$ & $0.0175^{*}$ & $0.000^{* *}$ \\
Linear regression & $0.000^{* *}$ & - & $0.000^{* *}$ & - & $0.935^{\mathrm{ns}}$ & - \\
Quadratic regression & $0.051^{\mathrm{ns}}$ & - & $0.317^{\mathrm{ns}}$ & - & $0.002^{* *}$ & - \\
Irrigation $\times$ density & $0.077^{\mathrm{ns}}$ & $0.004^{*}$ & $0.700^{\mathrm{ns}}$ & $0.030^{*}$ & $0.532^{\mathrm{ns}}$ & $0.000^{* *}$ \\
CV \% & 7.99 & 7.78 & 4.66 & 10.42 & 9.79 & 7.52 \\
\hline
\end{tabular}

${ }^{*}$ Significant at $5 \%$ probability by the F-test, ${ }^{* *}$ Significant at $1 \%$ probability by the $\mathrm{F}$-test, ${ }^{\mathrm{Ns}}$ Non-significant. 
Silva et al. (2010) reported a linear decrease in the NEP from 1.16 to 0.94 with an increase in the number of plants per $\mathrm{m}^{-2}$, in test populations of between 5.5 and 11 plants per $\mathrm{m}^{-2}$, using hybrids $\mathrm{D}$ 2B587, NB 4214, and 1565. A similar linear decrease in the NEP with an increase in the plant population was also reported by Kappes et al. (2011), using the hybrids XB 6010, XB 6012, XB 7253, XB 9003, and AG 9010; densities between 5 and 9 plants per $\mathrm{m}^{-2}$ resulted in a gradual average change from 1.0 to 0.92 ears per plant ${ }^{-1}$, respectively. According to Sangoi et al. (2002), increasing plant density enhances the apical dominance of the tassel on the ear, suppressing female fertility. We did not consider this in our study, which is potentially evidence that the decrease in the NEP may also be related to the characteristics of the hybrid genotype used and their tolerance of higher densities.

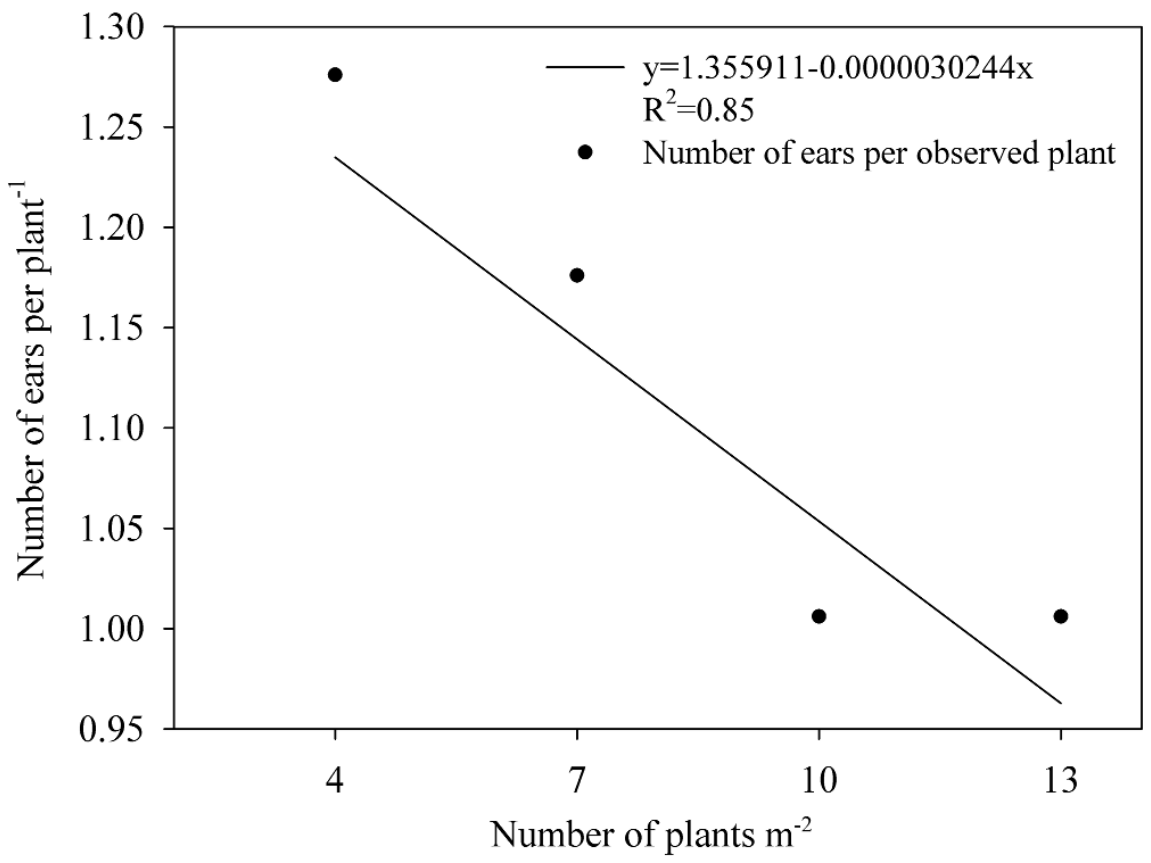

Figure 2. Number of ears per plant of maize grown at different plant densities.

For the number of grains per ear (NGE), a significant interaction was observed between plant density and irrigation level. At densities of 13 plants per $\mathrm{m}^{-2}$ (D4) and 10 plants per $\mathrm{m}^{-2}$ (D3), NGE increased with increasing levels of irrigation, until $100 \%$ of $\mathrm{Et}_{\mathrm{c}}$. At this point, the NGE observed was 381.74 for D4 and 421 for D3. This value was lower for the $125 \%$ of $\mathrm{Et}_{\mathrm{c}}$ treatment and irrigation levels less than $100 \%$ of $\mathrm{Et}_{\mathrm{c}}(0,50,75 \%)$.

At a density of seven plants per $\mathrm{m}^{-2}$ (D2), there was a gradual increase in the NGE until an irrigation level of $125 \%$ of $\mathrm{Et}_{\mathrm{c}}$, when 454 grains per ear were observed, which was the highest value recorded in this study (Figure 3). At a density of four plants per $\mathrm{m}^{-2}$ (D1), the highest NGE was observed at an irrigation level of $75 \%$ of $\mathrm{Et}_{\mathrm{c}}$.

Serpa et al. (2012) compared the density of hybrid plants, with full irrigation during critical periods of culture, and observed that the NGE was positively affected by irrigation in the first year of the study. They also observed an average of 469 grains per ear for the fully irrigated treatment over the two years of the study. This value was $15 \%$ higher compared with irrigation only during critical periods of the culture, which produced an average of
406 grains per ear. Serpa et al. (2012) also found that the NGE decreased linearly with an increase in the density of plants, for two of the four hybrids tested, partially corroborating the results observed in our study.

A similar result was reported by Farinelli et al. (2012) who observed a reduction in the NGE with increase in the population density of plants. At a density of four plants per $\mathrm{m}^{-2}$, they counted 578 grains per ear and 529 grains per ear at a density of eight plants per $\mathrm{m}^{-2}$, without irrigation, during a normal growing period at Jaboticabal, SP.

The decrease in the NGE at higher densities can be explained by increased intra-specific competition due to the increased density of plants. However, this effect was more acute in treatments of higher densities with smaller irrigation levels, possibly due to increased water demand by the larger population, resulting in an inadequate water supply for individual plants as water supplements are less in lower irrigation level treatments. From Figure 1, it is evident that irrigation was effective around the stage V5 period and during the tassel formation period, around 30 and $55 \mathrm{DAE}$, respectively. Therefore, it is highly likely that the decrease in the NGE in lower 
levels of irrigation treatments, with higher densities of plants, was due to the lower water supply. According to Sousa et al. (2015), a reduction in the NGE due to water shortage may be attributable to the lack of synchronization between the tassel formation stage, which generally occurs earlier, and the ear formation, which happens later. This causes the abortion of pollen grains, so that when stigmas sprout the pollen grains are no longer viable, resulting in ears with little or no grains.

Conversely, when we examined the irrigation level of $125 \%$ of $\mathrm{Et}_{\mathrm{c}}$ and the densities of four, 10, and 13 plants per $\mathrm{m}^{-2}$, there was a reduction in the NGE, compared with the $100 \%$ irrigation level. This was probably caused by excess water.

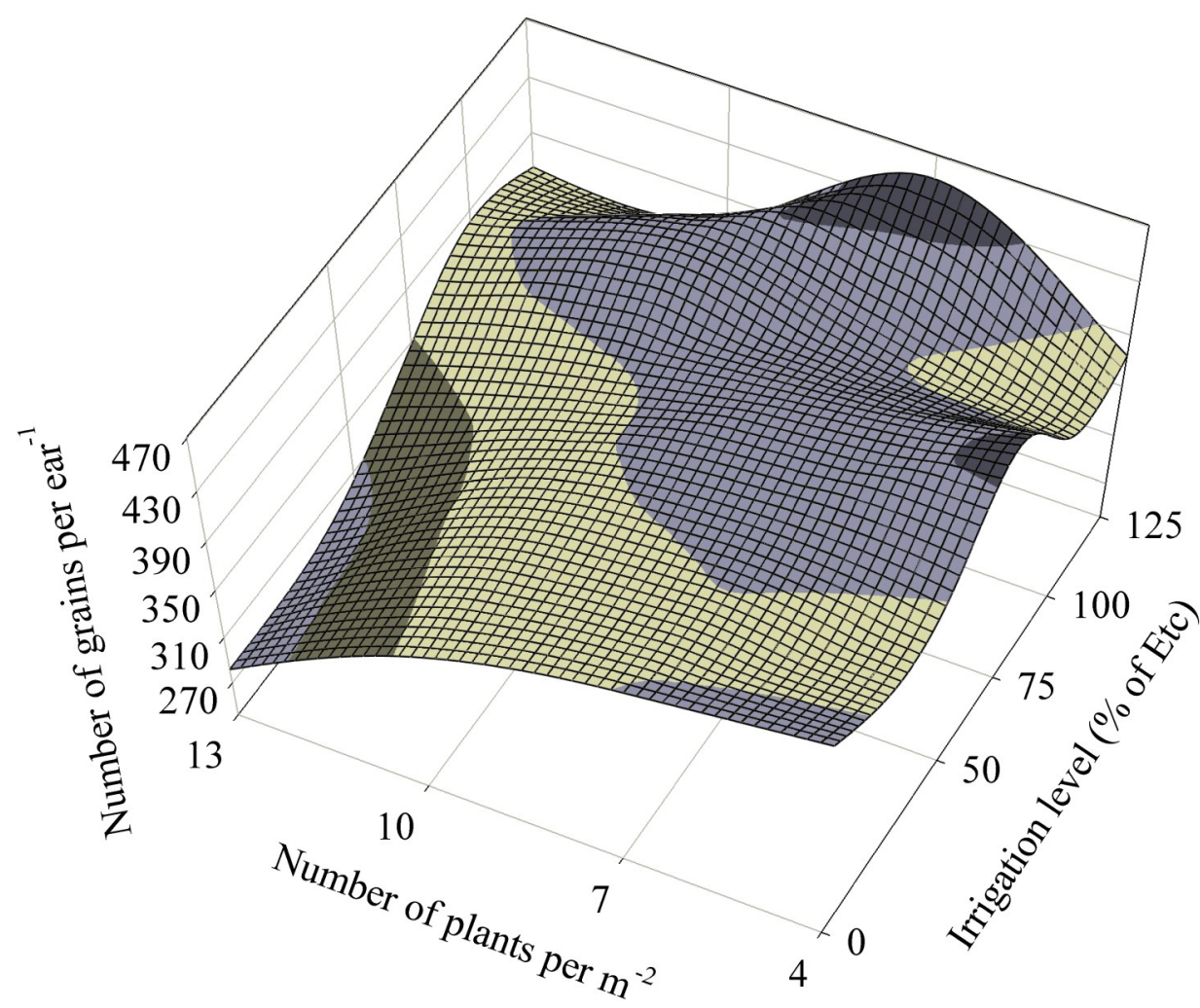

Figure 3. Number of grains per ear of maize plants grown at different irrigation levels and plant densities.

The weight of 100 grains (MCG) was affected independently by the level of irrigation and the density of plants (Table 2). The irrigation level that provided the largest grain mass was $95 \%$ of $\mathrm{Et}_{\mathrm{c}}$, estimated at $30.39 \mathrm{~g}$, while the smallest MCG, 28.22 $\mathrm{g}$, was observed for the treatment without any supplementary irrigation (Figure 4). Similar results were reported by Parizi et al. (2009), as irrigation levels of $80 \%$ and $100 \%$ of $\mathrm{Et}_{\mathrm{c}}$ produced the heaviest mass, approximately $31.0 \mathrm{~g}$, and the minimum value of only $28.0 \mathrm{~g}$ was observed in the $0 \%$ of $\mathrm{Et}_{\mathrm{c}}$ treatment. In addition, Pegorare et al. (2009) observed a linear reduction in the MCG with decreasing amounts of water, from $34.0 \mathrm{~g}$ to $31.5 \mathrm{~g}$, using irrigation levels of $100,75,50$, and $0 \%$ of $\mathrm{Et}_{\mathrm{c}}$.

The plant density that resulted in the highest MCG was four plants per $\mathrm{m}^{-2}$, with $30.78 \mathrm{~g}$, which decreased linearly with increasing density of plants (Figure 5). Similar results were reported by Abuzar et al. (2011) who also observed significant effects of plant density on the MCG; having studied plant densities between 4.0 and 14.0 plants per $\mathrm{m}^{-2}$, they found a heavier mass of grains at plants densities of 40,000 and 60,000 plants per $\mathrm{ha}^{-1}$, with a mass of 33.3 and $35 \mathrm{~g}$ for 100 grains, respectively. Conversely, the lightest mass of 100 grains was at a plant density of 140,000 plants per ha ${ }^{-1}$, with only 16.67 g. In contrast, Calonego et al. (2011) observed no significant statistical effect when testing densities of $4.5,6.0$, and 7.5 plants per $\mathrm{m}^{-2}$, showing that the average mass of the grains is independent from planting density.

The decrease in the MCG with increasing plant density can be attributed to increased intra-specific competition for resources available in the environment (SERPA et al., 2012). In addition, the increase in plant density leads to a smaller mass of individual dry matter in plants, which may have contributed to the smaller mass of grains, due to a reduced supply of photoassimilates to developing grains. 


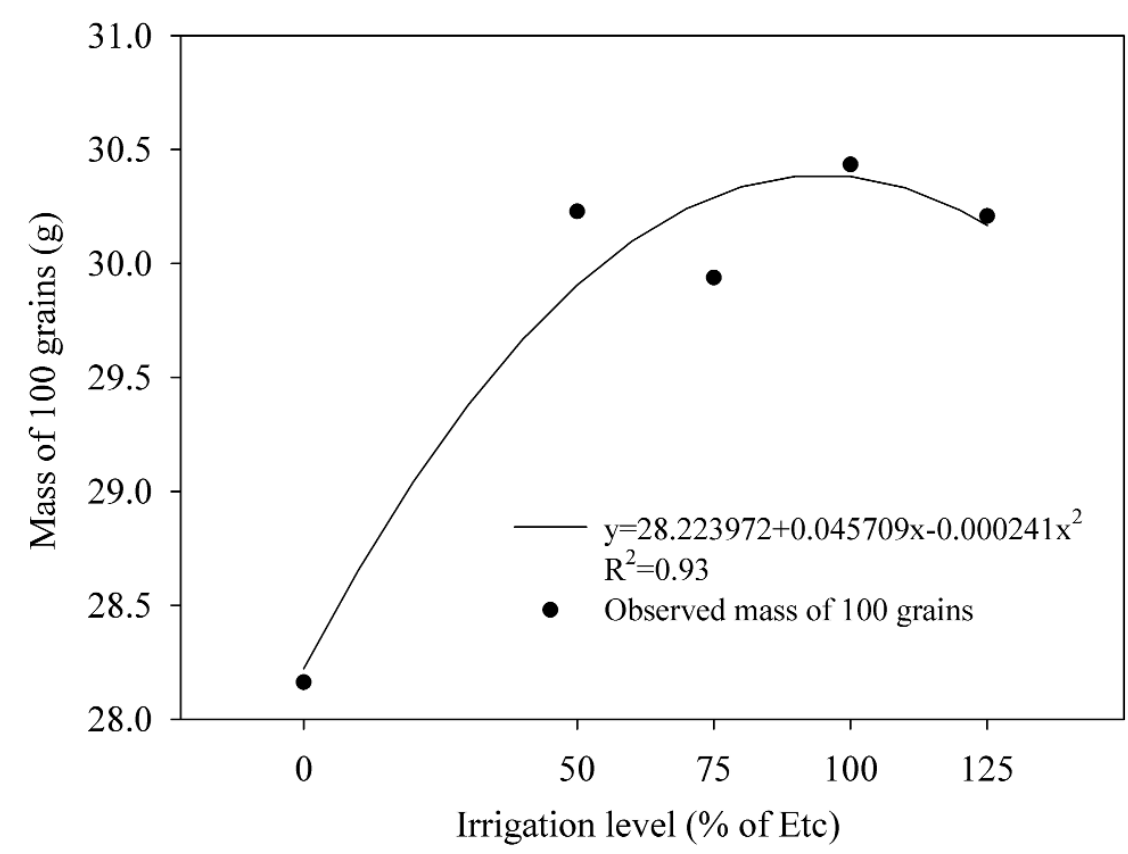

Figure 4. Mass of 100 grains (g) of maize grown at different irrigation levels.

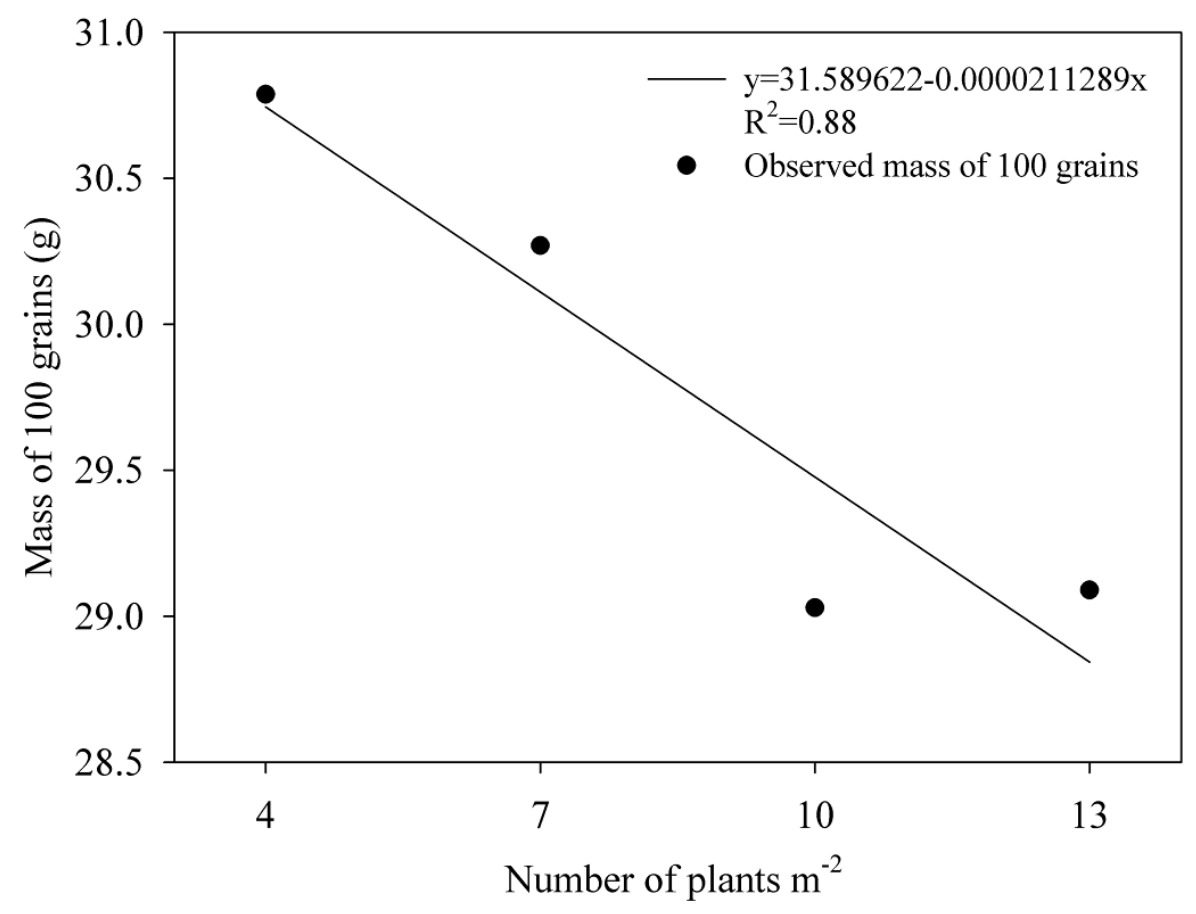

Figure 5. Mass of 100 grains (g) of maize grown at different plant densities.

For the yield of aboveground dry matter (DM), there was a significant interaction between the irrigation levels and plant densities studied. $\mathrm{T}_{2}\left(75 \%\right.$ of $\left.\mathrm{Et}_{\mathrm{c}}\right)$ with a plant density of 13 plants $\mathrm{m}^{-2}$ was the combination that showed the highest yield of DM $\left(29.61 \mathrm{t} \mathrm{ha}^{-1}\right)$. However, when plant density and the irrigation levels decreased, DM productivity also decreased (Figure 6). However, it should be noted that at the lowest density of plants used (four plants per $\mathrm{m}^{-2}$ ), DM productivity increased until an irrigation level of $75 \%$ of $\mathrm{Et}_{\mathrm{c}}$. Above this, there was a reduction in productivity of DM. The lowest DM productivity of $11.84 \mathrm{t} \mathrm{ha}^{-1}$ was observed in the $\mathrm{T}_{4}$ irrigation treatment with a density of four plants per $\mathrm{m}^{-2}$. Parizi et al. (2009) showed no statistically significant difference in the productivity of maize dry matter under different irrigation levels, between 0 and $120 \%$ of $\mathrm{Et}_{\mathrm{c}}$, in the municipality of Santiago-RS. However, Brachtvonel et al. (2012) studied the effect of plant densities between 30,000 and 105,000 plants per ha ${ }^{-1}$, and observed an increase in the production of dry matter mass per area with an increase in plant density, similar to our results. 
Although we observed an increase in productivity of DM at higher densities, conversely, there was a decrease in the individual DM of plants, as a result of the competition between individuals for resources, including soil fertility and solar radiation, among others. However, in this case, we also include water availability, as lower production of DM was associated with lower irrigation levels.

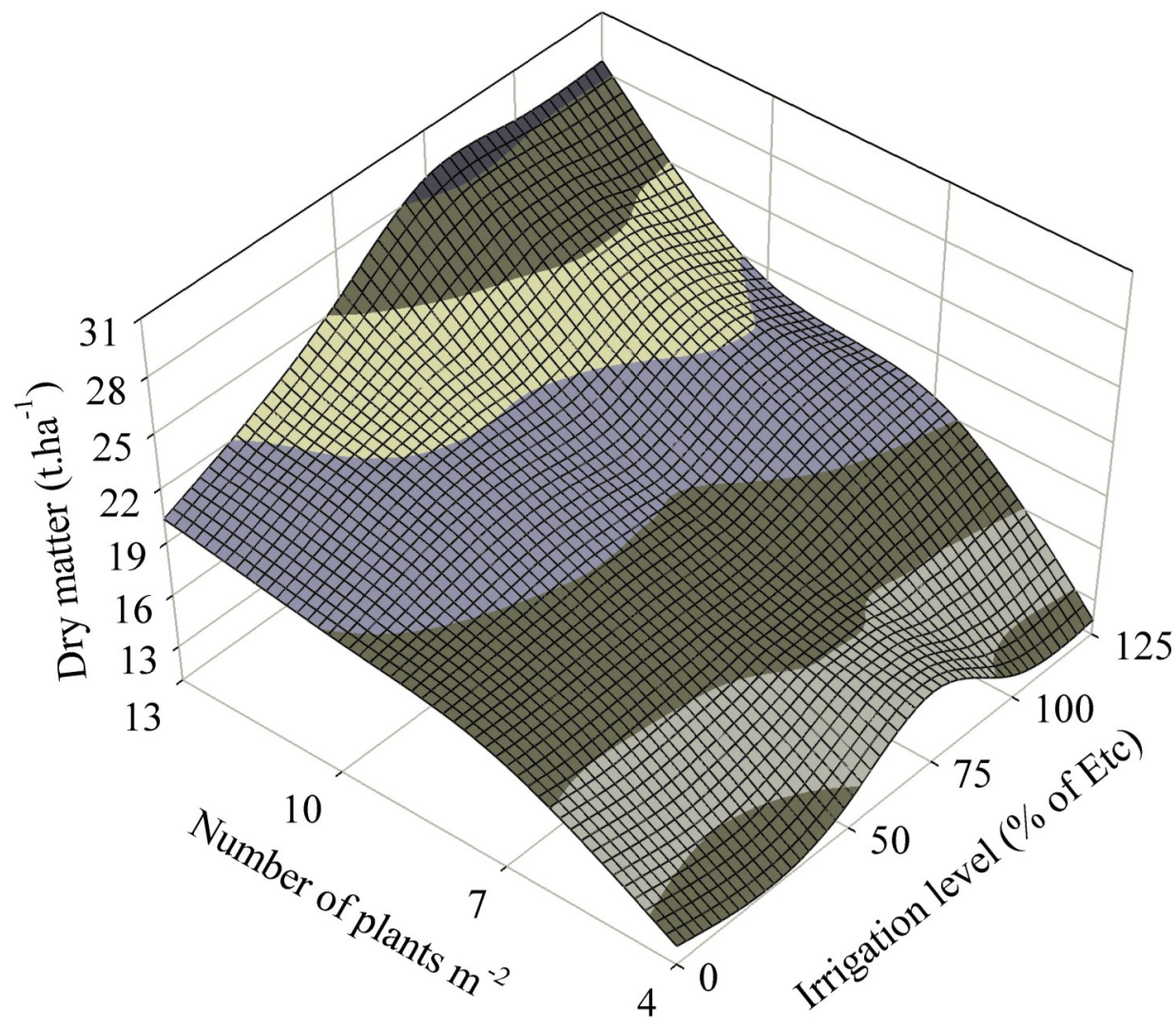

Figure 6. Aboveground dry matter productivity per area $\left(\mathrm{t} \mathrm{ha}^{-1}\right)$ of maize grown at different levels of irrigation and plant densities.

The harvest index (HI) did not change as a result of the irrigation levels used, with an average of 0.51 across all irrigation levels. This result corroborates Parizi et al. (2009), who also observed no statistically significant difference in the HI for different irrigation levels used on maize. However, when analyzing the effect of different densities of plants, the HI was affected, following a quadratic function (Figure 7). The highest $\mathrm{HI}$ was estimated at 0.53 for the plant density of 8.5 plants per $\mathrm{m}^{-2}$. According to Durães et al. (2002), as a general rule, when plant densities increase, notably above the level at which grain yield is higher, the HI decreases, which corroborates our observations in this study. However, conflicting data were presented by Brachtvonel et al. (2012) who reported that the HI did not change with different densities of plants.

According to Maddonni and Otegui (2006), one explanation is that the establishment of hierarchies with the so-called "dominated plants" decreases the ability of the plant to produce photoassimilates and allocating them to the grain, thus reducing the HI by producing smaller quantities of grain.

Grain productivity (Pgrains) was influenced by both an increase in plant density and by the irrigation levels used (Figure 8). For densities of seven, 10 , and 13 plants per $\mathrm{m}^{-2}$, Pgrains increased with an increase in irrigation level, reaching maximum productivity at $100 \%$ of $\mathrm{Et}_{\mathrm{c}}\left(\mathrm{T}_{3}\right)$, and decreasing again at an irrigation level of $125 \%$ of $\mathrm{Et}_{\mathrm{c}}$. The combination of $\mathrm{T}_{3}$ and the plant density of 13 plants per $\mathrm{m}^{-2}$ presented the highest Pgrains, producing $15.25 \mathrm{t} \mathrm{ha}^{-1}$. Moreover, for $\mathrm{T}_{3}$, a plant density of 10 plants per $\mathrm{m}^{-2}$ yielded $12.39 \mathrm{t} \mathrm{ha}^{-1}$, a plant density of seven plants per $\mathrm{m}^{-2}$ yielded $9.91 \mathrm{tha}$ -1 , and, finally, a plant density of four plants per $\mathrm{m}^{-2}$ yielded $6.09 \mathrm{t} \mathrm{ha}^{-1}$.

When we examined each plant density for $\mathrm{T}_{0}$ (without irrigation) separately, we observed that yield was lower than with all other irrigation levels. The density of 13 plants per $\mathrm{m}^{-2}$ provided the greatest grain yield compared with all other densities. However, we note that, in $\mathrm{T}_{0}$, the yield at densities of 13, 10, and seven plants per $\mathrm{m}^{-2}$ showed similar values of around 9.79, 9.77, and $9.46 \mathrm{t} \mathrm{ha}^{-1}$, respectively. In this context, the choice of such densities did not significantly modify productivity. However, a plant density of four plants per $\mathrm{m}^{-2}$ in $\mathrm{T}_{0}$ yielded only $5.17 \mathrm{t} \mathrm{ha}^{-1}$, which was the lowest in the 
study. Thus, for maize cultures that will not use supplemental irrigation, one can use densities between seven and 13 plants per $\mathrm{m}^{2}$. However, due to the high cost of maize seeds, using seven plants per $\mathrm{m}^{-2}$ may be a better choice.

At a density of seven plants per $\mathrm{m}^{-2}$, an irrigation level of $125 \%$ of $\mathrm{Et}_{\mathrm{c}}$ presented the greatest Pgrains (10.26 $\left.\mathrm{t} \mathrm{ha}^{-1}\right)$. Lower irrigation levels showed a gradual decrease in productivity.

A plant density of four plants per $\mathrm{m}^{-2}$ presented the lowest Pgrains, relative to other plant densities and irrespective of the irrigation levels used. Therefore, this plant density appears technically unfeasible for maize cultures, irrespective of whether supplemental irrigation is applied.

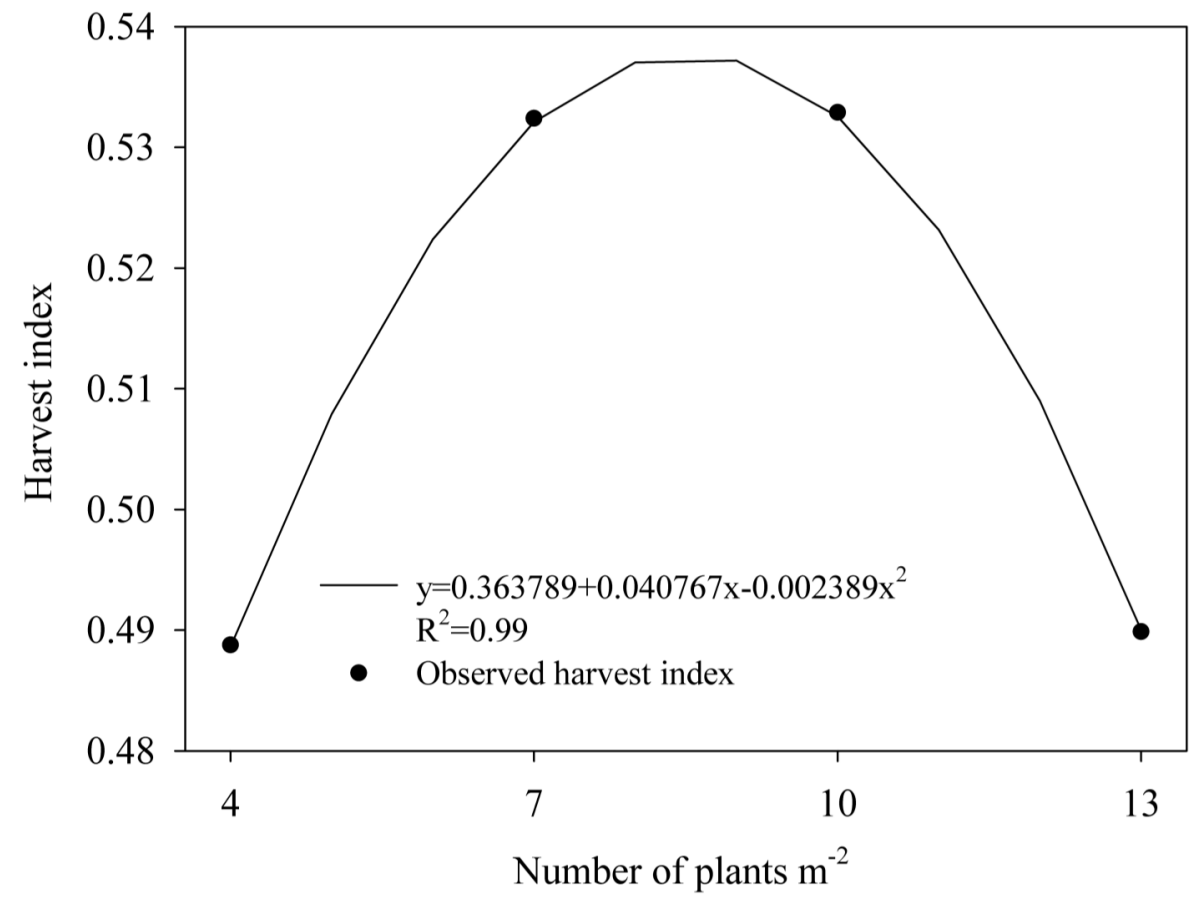

Figure 7. Harvest index of maize grown at different plant densities.

El-Hendawy et al. (2008) found a significant interaction between irrigation levels and plant densities; the treatment that maximized yield for maize grain in the climatic conditions of the study location in Egypt was a combination of $100 \%$ of $\mathrm{Et}_{\mathrm{c}}$ irrigation rate and a density of 7.1 plants per $\mathrm{m}^{-2}$. Such data corroborate Parizi et al. (2009), who studied only irrigation levels and found greater productivity with $100 \%$ of $\mathrm{Et}_{\mathrm{c}}$ with $12.84 \mathrm{t} \mathrm{ha}^{-1}$, in the municipality of Santiago-RS. Similarly, Beiragi et al. (2011) observed a reduction of $71.54 \%$ in grain yield when the fraction of soil water depletion reached $80 \%$.
Serpa et al. (2012) studied maize hybrids at a range of densities between 5 and 11 plants per $\mathrm{m}^{-2}$, using full irrigation during critical periods of the culture, and found that, based on the average of hybrids, a linear increment in the growth of plants in the population. With full irrigation management, they observed maximum productivity of $16.3 \mathrm{t} \mathrm{ha}^{-1}$, at a plant density of 11 plants per $\mathrm{m}^{-2}$, a $31 \%$ higher yield than for the plant density of five plants per $\mathrm{m}^{-2}$. Serpa et al. (2012) observed a quadratic effect of irrigation during the most critical periods of the culture. In this case, the greatest Pgrains was $13.2 \mathrm{t}$ $\mathrm{ha}^{-1}$, estimated for a density of 10.4 plants per $\mathrm{m}^{-2}$. 


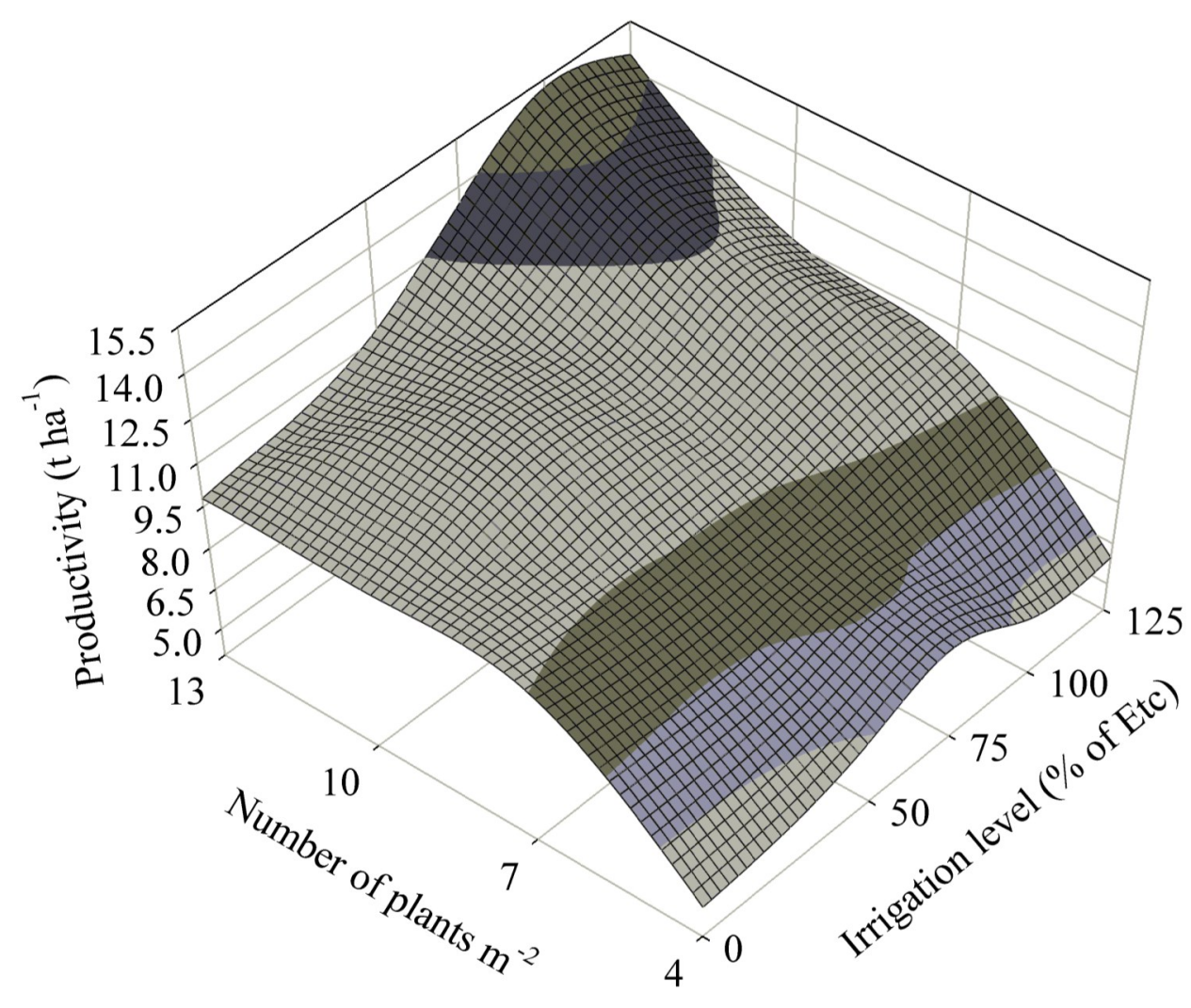

Figure 8. Productivity of maize grains grown at different levels of irrigation and plant densities.

\section{CONCLUSION}

The number of grains per ear, mass of 100 grains, and grain productivity were all influenced by irrigation level.

The plant density and irrigation level influenced the number of grains per ear, the mass of 100 grains, and grain productivity.

The highest yield of winter maize grains was observed in the combination of 13 plants per $\mathrm{m}^{-2}$ and irrigation level of $100 \%$ of $\mathrm{Et}_{\mathrm{c}}$.

Specific densities of plants maximized the maize yield at each irrigation level applied. Therefore, the choice of plant density is a critical variable in the second crop maize, significantly influencing the components of production.

\section{REFERENCES}

ABUZAR, R. et al. Effect Of Plant Population Densities On Yield Of Maize, The Journal of Animal \& Plant Sciences, Nairobi, v. 21, n. 4, p. 692-695, 2011.

BASSO, C. J. et al. Vinhaça como fonte de potássio: resposta da sucessão aveia-preta/milho silagem/ milho safrinha e alterações químicas do solo na Região Noroeste do Rio Grande do Sul. Ciência
Rural, Santa Maria, v. 43, n. 4, p. 596-602, 2013.

BEIRAGI, M. A. et al. A study of morphological basis of corn (Zea mays L.) yield under drought stress condition using correlation and path coefficient analysis. Journal of Cereals and Oilseeds, Lagos, v. 2, n. 2, p. 32-37, 2011.

BERGAMASCHI, H.; MATZENAUER, R. O milho e o clima. 1. ed. Porto Alegre, RS: Emater-Ascar, 2014. 84 p.

BERGAMASCHI, $\mathrm{H}$. et al. Déficit hídrico e produtividade na cultura do milho. Pesquisa Agropecuária Brasileira, Brasília, v. 41, n. 2, p. 243-249, 2006.

BRACHTVOGEL E. L. et al. População, arranjo de plantas uniforme e a competição intraespecífica em milho. Revista Trópica - Ciências Agrárias e Biológicas, Chapadinha, v. 6, n. 1, p. 75-83, 2012.

BRACHTVOGEL, E. L. et al. Densidades populacionais de milho em arranjos espaciais convencional e equidistante entre plantas. Revista Ciência Rural, Santa Maria, v. 39, n. 8, p. 23342339, 2009.

BÜCHELE, F. A.; SILVA, J. A. da. Manual prático de irrigação por aspersão em sistemas 
convencionais. Florianópolis: EPAGRI, 1992. 81p. (EPAGRI. Boletim Técnico, 58).

CALONEGO, J. C. et al. Produtividade e crescimento de milho em diferentes arranjos de plantas. Revista Agrarian, Dourados, v. 4, n. 12, p. 84-90, 2011.

DOORENBOS, J.; KASSAM, A. H. Efectos del água sobre el rendimiento de los cultivos. Roma: FAO, 1979. 212 p. (Estudio FAO: Riego y Drenaje, $33)$.

DURÃES, F. O. M.; MAGALHÃES, P. C.; OLIVEIRA, A. C. Índice de colheita genético e as possibilidades da genética fisiológica para melhoramento do rendimento de milho. Revista Brasileira de Milho e Sorgo, Sete Lagoas, v. 1, n. 1, p. 33-40, 2002.

EL-HENDAWY, E. E. S. et al. Irrigation rate and plant density effects on yield and water use efficiency of drip-irrigated corn. Agricultural water management, Amsterdam, v. 95, n. 7, p. 836-844, 2008.

FANCELLI, A. L. Ecofisiologia de plantas de lavouras. In: CARLESSO, R. et al. Irrigação por aspersão no Rio Grande do Sul. Santa Maria, 2001. p. 59-73.

FARINELLI, R.; PENARIOL, F. G.; FORNASIERI FILHO, D. Características agronômicas e produtividade de cultivares de milho em diferentes espaçamentos entrelinhas e densidades populacionais. Científica, Jaboticabal, v. 40, n. 1, p. 21-27, 2012

FERREIRA, D. F. Sisvar - sistema de análise de variância para dados balanceados. Lavras, MG: UFLA, 1998. 19 p.

KAPPES, C. et al. Desempenho de híbridos de milho em diferentes arranjos espaciais de plantas. Revista Bragantia, Campinas, v. 70, n. 2, p. 334-343, 2011.

KOPP, L. M. et al.; Simulação da necessidade hídrica e estimative de produtividade para cultura do milho em municípios do RS. Revista Brasileira de Milho e Sorgo, Sete Lagoas, v. 14, n. 2, p. 235-246, 2015.

MADDONNI, G. A.; OTEGUI, M. E. Intra-specific competition in maize: contribution of extreme plant hierarchies to grain yield, grain yield components and kernel composition. Field Crops Research, Amsterdam, v. 97, n. 2-3, p. 155-166, 2006.

MINUZZI, R. B.; RIBEIRO, A. J. Requerimento de água para irrigação do milho em Santa Catarina durante eventos La Niña. Revista Brasileira de Engenharia Agrícola e Ambiental, Campina Grande, v. 16, n. 12, p. 1330-1337, 2012.

PARIZI, A. R. C. et al. Efeito de diferentes estratégias de irrigação suplementar sobre a produção de grãos e seus componentes na cultura do milho. Irriga, Botucatu, v. 14, n. 3, p. 254-267, 2009.

PEAK, A. S.; ROBERTSON, M. J.; BIDSTRUP, R. Optimising maize plant population and irrigation strategy on the darling downs: a simulation analysis. In: TRIENNIAL CONFERENCE，6th，2006, Darlington Point. Anais... Darlington Point: Maize association of Australia, 2006.

PEGORARE, A. B. et al. Irrigação suplementar no ciclo do milho "safrinha" sob plantio direto. Revista Brasileira de Engenharia Agrícola e Ambiental, Campina Grande, v. 13, n. 3, p. 262-271, 2009.

PIANA, A. T. et al. Densidade de plantas de milho em semeadura precoce no Rio Grande do Sul. Revista Ciência Rural, Santa Maria, v.38, n. 9, p. 2608-2612, 2008.

RITCHIE, S. W.; HANWAY, J. J.; BENSON, G. O. How a corn plant develops? Ames: Iowa State University, 1993. (Special report, 48).

SANGOI, L. et al. Bases morfológicas para maior tolerância dos híbridos modernos de milho a altas densidades de plantas. Revista Bragantia, Campinas, v. 61, n. 2, p. 101-110, 2002.

SERPA, M. S. et al. Densidade de plantas em híbridos de milho semeados no final do inverno em ambientes irrigados e de sequeiro. Pesquisa Agropecuária Brasileira, Brasília, v. 47, n. 4, p. 541-549, 2012

SILVA, P. R. F.; ARGENTA, G.; SANGOI, L. Fatores determinantes da escolha da densidade de plantas em milho. In: REUNIÃO TÉCNICA CATARINENSE DE MILHO E FEIJÃO, 4. 2003, Lages. Anais... Lages: CAV-UDESC, 2003, p. $25-$ 29.

SILVA, P. R. F. et al. Adequação da densidade de plantas à época de semeadura em milho irrigado. Revista de Ciências Agroveterinárias, Lages, v. 9, n. 1, p. 48-57, 2010.

SOUSA, R. S. et al.; Desempenho produtivo de genótipos de milho sob déficit hídrico. Revista Brasileira de Milho e Sorgo, Sete Lagoas, v. 14, n. 1, p. 49-60, 2015.

STRECK, E. V. et al. Solos do Rio Grande do Sul. 
2. ed. Porto Alegre, RS: EMATER, 2008. 222 p.

TAKASU, A. T. et al. Desempenho agronômico do milho sob diferentes arranjos populacionais e espaçamento entrelinhas. Revista Agrarian, Dourados, v. 7, n. 23, p. 34-41, 2014.

VIEIRA, V. M. et al. Rendimento de grãos de milho sob diferentes sistemas de irrigação por aspersão.

Irriga, Botucatu, v. 18, n. 3, p. 471-485, 2013. 